Simposium I Jaringan Perguruan Tinggi untuk Pembangunan Infrastruktur Indonesia, 2016

\title{
Hubungan Antara Penganggaran Pekerjaan Konstruksi Pemerintah dengan Kualitas dan Pemanfaatan Infrastruktur Indonesia
}

\author{
Angga Eka Wicaksana, S.T., M.Med Kom
}

Universitas Airlangga, Kampus C Mulyorejo, Surabaya 60115, Indonesia

\begin{abstract}
Banyak proyek infrastruktur di Indonesia sampai saat ini belum termanfaatkan dengan baik dan berdampak pada kualitas infrastruktur terbangun. Kondisi ini secara tidak langsung akan berdampak tidak baik terhadap pembangunan sosial dan ekonomi. Banyak faktor yang mempengaruhi rendahnya pemanfaatan infrastruktur, salah satunya ditengarai berkaitan dengan penganggaran pada setiap tahunnya. Akan tetapi sampai saat ini masih sangat sedikit penelitian yang secara khusus melihat bagaimana keterkaitan antara Penganggaran Pekerjaan Konstruksi Pemerintah Dengan Kualitas dan Pemanfaatan Infrastruktur Indonesia di Indonesia. Beranjak dari kondisi ini maka makalah ini dimaksudkan untuk melakukan kajian terhadap permasalahan pada penganggaran pekerjaan konstruksi pemerintah yang memberikan pengaruh langsung maupun tidak langsung terhadap Kualitas dan Pemanfaatan Infrastruktur Indonesia. Kajian ini merupakan kajian deskriptif terhadap berbagai hasil penelitian, literatur, peraturan perundangan terkait, serta berbagai informasi yang relevan. Hasil penelusuran memperlihatkan masih terdapat berbagai permasalahan baik teknis maupun non-teknis pada penganggaran pekerjaan konstruksi pemerintah yang secara langsung maupun tidak langsung akan mempengaruhi Kualitas dan Pemanfaatan Infrastruktur Indonesia. Terdapat benang merah antara Penganggaran Pekerjaan Konstruksi Pemerintah Dengan Kualitas dan Pemanfaatan Infrastruktur Indonesia, dimana kegagalan pencapaian quality assurance ini secara tidak langsung akan mempengaruhi pemanfaatan infrastruktur terbangun. Untuk itu perlu dipastikan bahwa pengadaan pekerjaan konstruksi yang dilaksanakan terencana dengan baik serta berjalan sesuai dengan tujuan dan target yang telah ditetapkan. Karena jika kegiatan pengadaan direncanakan dan dikelola dengan baik, maka akan mudah mengidentifikasi permasalahan pada setiap tahapan pengadaan dan rekomendasi perbaikan sehingga nilai manfaat bagi masyarakat dari nilai pengadaan yang dilaksanakan akan dapat dipenuhi.
\end{abstract}

Keywords: Anggaran Pemerintah, Pekerjaan Konstruksi, Kualitas, Pemanfaatan, Infrastruktur Indonesia ;

\section{Pendahuluan}

Banyak proyek infrastruktur di Indonesia sampai saat ini belum termanfaatkan dengan baik dan berdampak pada kualitas infrastruktur terbangun. Kondisi ini secara tidak langsung akan berdampak tidak baik terhadap pembangunan sosial dan ekonomi. Banyak faktor yang mempengaruhi rendahnya pemanfaatan infrastruktur, salah satunya ditengarai berkaitan dengan penganggaran pada setiap tahunnya. Akan tetapi sampai saat ini masih sangat sedikit penelitian yang secara khusus melihat bagaimana keterkaitan antara Penganggaran Pekerjaan Konstruksi Pemerintah Dengan Kualitas dan Pemanfaatan Infrastruktur Indonesia di Indonesia.

\subsection{Dasar Teori}

\subsection{Kontrak dan Tahun Anggaran}

Dalam lingkup pengelolaan keuangan negara terdapat dua wilayah pengelolaan anggaran dan pengelolaan barang. Dalam menilai pertanggungjawaban pengelolaan keuangan negara Badan Pemeriksa Keuangan meneliti dari sisi akuntabilitas proses dan pencapaian kinerja. Sehingga dengan itu PPK sebagai penegak amanat UUD wajib menyusun kontrak dengan memperhatikan akuntabilitas proses dan pencapaian kinerja. Untuk itu komponen utama kontrak disisi pengelolaan keuangan negara adalah komponen pembebanan dana pada tahun anggaran dan pelaksanaan anggaran. Pembebanan dana pada tahun anggaran harus terjaga akuntabilitasnya dari sisi administratif. Pelaksanaan anggaran harus terjaga akuntabilitasnya secara administratif sekaligus juga kinerja secara ekonomis, efisien dan efektif.

\subsubsection{Pengadaan Pekerjaan Konstruksi}

Pengadaan konstruksi dapat didefinisikan dengan banyak cara dan telah menjadi topik yang kompleks dan sulit. Hal ini dikarenakan proses pengadaan tidak hanya mengacu pada apa yang akan dibeli, tetapi juga menentukan metode yang akan digunakan untuk mendapatkan bangunan dan fasilitas infrastruktur lainnya (Hughes et.al, 2006:7). Pengadaan adalah proses utama dari pelaksanaan dan pemeliharaan pekerjaan konstruksi yang selalu membutuhkan barang dan jasa dari organisasi lain untuk memenuhi kebutuhannya (Watermeyer, 2012:1). Mohsini \& Davidson (1989:86), mendefinisikan pengadaan konstruksi sebagai proses akuisisi bangunan baru atau ruang dalam bangunan, baik dengan pembelian langsung, menyewa atau leasing dari pasar terbuka, atau dengan merancang dan membangun fasilitas untuk memenuhi kebutuhan khusus. 


\subsubsection{Kondisi Infrastruktur di Indonesia}

Infrastruktur memegang peranan penting sebagai salah satu roda penggerak pertumbuhan ekonomi dan pembangunan sektor ini menjadi pondasi pemerintah dalam melaksanakan pembangunan secara keseluruhan. Alokasi dana publik yang digunakan untuk pembiayaan pembangunan infrastruktur relatif besar. Pemerintah sendiri menargetkan belanja untuk pembangunan infrastruktur sampai 2019 mencapai Rp 4.796 triliun sedangkan APBN dan APBD menyumbang Rp 2.817 triliun.

Akan tetapi, sampai saat ini kualitas infrastruktur di Indonesia dinilai masih rendah dan telah sejak lama menjadi perhatian Bank Dunia maupun lembaga donor internasional lainnya. Kerusakan berbagai bangunan pemerintah yang baru seumur jagung kerap terjadi, hasil pekerjaan yang tidak sesuai spesifikasi, cepatnya masa pakai bangunan berakhir, dan lain sebagainya. Global Competitiveness Report melaporkan untuk tahun 2013-2014 kondisi infrastruktur Indonesia secara keseluruhan berada pada urutan ke-82 dari 148 negara. Kondisi infrastruktur yang buruk secara tidak langsung akan memberikan dampak buruk terhadap masyarakat. Beberapa permasalahan yang menyebabkan buruknya kondisi infrastruktur nasional antara lain pembangunan proyek infrastruktur yang kurang terencana; studi kelayakan (feasibility studies) yang kurang memadai; adanya indikasi praktik korupsi pada proyek infrastruktur yang menyebabkan rendahnya kualitas infrastruktur; minimnya dana pembangunan, perawatan, dan rehabilitasi infrastruktur; faktor fragmentasi dan "high cost" pada proses pengadaan; transaksi biaya tinggi; kurangnya kompetisi; kontrol dari pemerintah kurang dan kontrol yang lemah pada tahap konstruksi (Ray, 2012:12).

\section{Metode Penelitian}

Makalah ini merupakan hasil kajian deskripstif dari berbagai literatur, peraturan perundangan terkait dan berbagai informasi yang relevan dengan pelaksanaan penganggarab pekerjaan konstruksi pemerintah. Penelitian terkait pelaksanaan pengadaan pekerjaan konstruksi terutama pada proyek pemerintah relatif sangat sedikit. Dengan adanya pemaparan hasil kajian teoritis pada makalah ini diharapkan akan membuka wacana pemahaman bagi semua pihak.

\section{Hasil dan Pembahasan}

Proyek konstruksi memiliki keterbatasan baik dari segi biaya, mutu maupun waktu, karakteristik ini menjadi perbedaan dengan proyek lainnya, selain itu kompleksitas pekerjaannya juga berbeda. Keterlibatan banyak pihak dalam pekerjaan konstruksi menjadikan pengadaan sebagai suatu proses akuisisi dari berbagai sumber daya proyek dalam merealisasikan fasilitas yang akan dibangun (International Labor Office, 1984). Dengan karakteristik dan kompleksitas pekerjaan konstruksi, maka pemilihan sistem pengadaan harus dilakukan dengan mempertimbangkan prinsip-prinsip yang mendukung —best value for money\| (Onosakponome et.al., 2011). Disisi lain, sampai saat ini industri konstruksi masih kerap menuai kritik di banyak negara, terutama terkait masalah inefisiensi dari hasil pelaksanaan pekerjaan seperti waktu dan pembengkakan biaya, produktivitas yang rendah, kualitas buruk dan kepuasan pelanggan yang tidak memadai (Latham, 1994; Egan, 1998; Ericsson, 2002; Chan et al., 2003). Di antara banyak bidang kendala yang dihadapi oleh industri konstruksi di negara-negara berkembang merupakan kendala yang ada dalam proses pengadaan pekerjaan konstruksi (Turin, 1973; Ofori, 1980; Edmonds \& Miles, 1984; World Bank, 1984; Wells, 1986; Wang, 1987; 1991; Sharif \& Morledge, 1996; Morledge, 1996; Sharif, 1996) yang menyebabkan kurangnya efektivitas proses yang dilaksanakan.

Beberapa peneliti (Turin, 1973; Ofori, 1980; Edmonds \& Miles, 1984; Wells, 1986) menyatakan bahwa pengadaan konstruksi yang tidak efektif akan mempengaruhi output dan selanjutnya akan menghambat pertumbuhan industri konstruksi. Sementara peneliti lainnya (Turin, 1973; Ofori, 1980; Edmonds \& Miles, 1984, World Bank, 1984; Wells, 1986; Wang, 1987; 1991; Master Builders, 1989-1990, Miles \&Neale, 1991; Morledge, 1996) menyimpulkan bahwa kendala dalam proses pengadaan bisa disebabkan oleh salah satu atau kombinasi dari dua atau lebih faktor-faktor berikut: unavailability, insufficiency atau inappropriate dari sumber daya atau lembaga (Rashid \& Morledge, 1998).

Hasil penilaian lembaga internasional dan nasional memperlihatkan masih banyak celah maupun kelemahan dari sistem dan prosedur pengadaan pemerintah di Indonesia yang saat ini berjalan. Sistem dan prosedur yang berjalan mengasumsikan pengelola pengadaan sebagai profesional, sehingga dapat mengambil keputusan secara profesional berdasarkan pengalaman dan pengetahuannya. Sebaliknya, sistem dan prosedur yang ada juga berasumsi kredibilitas pengelola pengadaan sangat rendah, sehingga masyarakat tidak memiliki — trustl pada pengelola pengadaan. Hal ini terlihat dari masih banyaknya penyimpangan dalam proses pengadaan terutama pengadaan pemerintah (World Bank, 2001; OECD, 2005, PPI, 2010; LKPP, 2011)

Sekarang kita bahas judul tulisan ini Kontrak dan Tahun Anggaran. Pada pasal 50 tentang Jenis Kontrak pada ayat 4 menyebutkan bahwa Kontrak Pengadaan Barang/Jasa berdasarkan pembebanan Tahun Anggaran, terdiri atas: Kontrak Tahun Tunggal; dan Kontrak Tahun Jamak. Pasal 52 kemudian memberikan definisi atas jenis kontrak ini.

Kontrak Tahun Tunggal merupakan Kontrak yang pelaksanaan pekerjaannya mengikat dana anggaran selama masa 1 (satu) Tahun Anggaran. Kontrak Tahun Jamak merupakan Kontrak yang pelaksanaan pekerjaannya untuk masa lebih dari 1 (satu) Tahun Anggaran atas beban anggaran. Struktur kalimat pasal 52 ayat 1 dan ayat 2 sangat berbeda sekali, terkait dua domain besar pembentuk definisi pengelolaan keuangan negara, yaitu Anggaran dan Barang/Kinerja seperti yang dibahas diawal. Ayat 1 
menegaskan bahwa yang pelaksanaan pekerjaan (kinerja) diikat oleh anggaran selama masa 1 tahun anggaran. Dapat ditafsirkan bahwa meski pelaksanaan pekerjaan melewati tahun anggaran selama masih menggunakan anggaran pada tahun anggaran awal masih masuk dalam kategori tahun tunggal. Kemudian coba kita gunakan tabel Perbandingan Definisi Kontrak Atas Pembebanan Tahun Anggaran antara Keppres 80/2003 dan Perpres 54/2010 khusus Kontrak Tahun Jamak. Logika pemisahan antara Anggaran dan Kinerja semakin jelas. Pada Keppres 80/2003 pasal 30 ayat 8 masih membunyikan kalimat mengikat dana anggaran untuk masa lebih dari 1 tahun. Hal ini menimbulkan keterbatasan konsep tahun jamak disisi pengadaan, karena pelaksanaan pengadaan (kinerja) terikat dengan anggaran yang melewati tahun begitu juga sebaliknya. Sementara Perpres 54/2010 pasal 52 ayat 2 menjelaskan bahwa yang melewati tahun anggaran adalah hanya pelaksanaan pekerjaan (kinerja) sedangkan dana anggaran tidak diikat.

Ilustrasi sederhananya dalam perencanaan, waktu pelaksanaan pekerjaan dalam dokumen pengadaan adalah 14 bulan. Kemudian penyedia menawarkan masa pelaksanaan hanya 12 bulan dan realisasi penyelesaian ternyata 11 bulan. Pada Keppres 80/2003 penyedia tidak dapat dibayar pada tahun anggaran tersebut karena dana anggaran juga terikat lebih dari 1 tahun. Sementara pada Perpres 54/2010 tidak menutup kemungkinan dapat dibayar tahun berkenaan apabila anggaran cukup untuk membayar pada tahun berkenaan.

Table 1 Perbandingan Definisi Kontrak Atas Pembebanan Tahun Anggaran

Keppres 80/2003

Pepres 54/2010

\begin{tabular}{|c|c|}
\hline Pasal 30 ayat 7 dan 8 & Pasal 52 ayat 1 dan 2 \\
\hline $\begin{array}{l}\text { Kontrak tahun tunggal adalah kontrak pelaksanaan } \\
\text { pekerjaan yang mengikat dana anggaran untuk masa } 1 \\
\text { (satu) tahun anggaran. }\end{array}$ & $\begin{array}{l}\text { Kontrak Tahun Tunggal merupakan Kontrak yang } \\
\text { pelaksanaan pekerjaannya mengikat dana anggaran } \\
\text { selama masa } 1 \text { (satu) Tahun Anggaran. }\end{array}$ \\
\hline $\begin{array}{lrrr}\text { Kontrak tahun jamak adalah } & \text { kontrak } & \text { pelaksanaan } \\
\text { pekerjaan } & \text { yang } & \text { mengikat } & \text { dana } \\
\text { anggaran untuk masa lebih dari } 1 \text { (satu) tahun anggaran. }\end{array}$ & $\begin{array}{l}\text { Kontrak Tahun Jamak merupakan Kontrak yang } \\
\text { pelaksanaan pekerjaannya untuk masa lebih dari } 1 \\
\text { (satu) Tahun Anggaran atas beban anggaran. }\end{array}$ \\
\hline
\end{tabular}

Kita lihat PMK 25/PMK.05/2012 pasal 2 ayat (3) bahwa Pekerjaan yang dilanjutkan pada Tahun Anggaran berikutnya sebagaimana dimaksud pada ayat (1) tidak termasuk pekerjaan Kontrak tahun jamak (multiyears contract). Sementara Perpres 54/2010 pasal 52 ayat 2 tegas menyebutkan pelaksanaan pekerjaan melebihi satu tahun anggaran atas beban anggaran adalah kontrak tahun jamak. Seandainya beban anggaran tetap pada tahun anggaran 2012, meski pelaksanaan melewati tahun anggaran tentu masih dapat dikatakan kontrak tidak termasuk tahun jamak. Sesuai UU nomor 12 tahun 2011, tentang Pembentukan Peraturan Perundang-Undangan, peraturan setingkat kementerian hendaknya tidak bertentangan dengan peraturan diatasnya. Termasuk Perpres 54/2010 terlebih lagi UU. Dari keseluruhan pembahasan ada dua mainstream utama yang melingkupi langkahlangkah akhir tahun yaitu pilihan pembebanan dana anggaran pada tahun anggaran bersangkutan melalui perpanjangan jaminan pembayaran dan pembebanan dana anggaran pada Tahun Anggaran berikutnya. Berikut tabel perbandingan yang semoga dapat mempermudah pemahaman.

Table 2. Perbandingan Solusi Akhir Tahun untuk Kasus Keterlambatan

\begin{tabular}{|c|c|c|}
\hline Uraian & Dibebankan Tahun Anggaran Bersangkutan & $\begin{array}{c}\text { Dibebankan Tahun Anggaran } \\
\text { Berikutnya }\end{array}$ \\
\hline $\begin{array}{l}\text { Pencapaian Output Tahun Anggaran } \\
\text { Bersangkutan }\end{array}$ & Maksimal & Maksimal \\
\hline $\begin{array}{l}\text { Penyerapan Anggaran Tahun } \\
\text { Bersangkutan }\end{array}$ & Maksimal & Tidak Maksimal \\
\hline Revisi Tahun Anggaran Berikutnya & Tidak Perlu & Perlu \\
\hline $\begin{array}{l}\text { Kepastian Ketersediaan Anggaran Tahun } \\
\text { Berikutnya }\end{array}$ & $\begin{array}{l}\text { Tidak mempengaruhi tahun anggaran } \\
\text { berikutnya }\end{array}$ & $\begin{array}{l}\text { Tahun anggaran berikutnya belum tentu } \\
\text { tersedia dana yang cukup }\end{array}$ \\
\hline $\begin{array}{l}\text { Pengaruh terhadap Output Tahun } \\
\text { Berikutnya }\end{array}$ & $\begin{array}{l}\text { Tidak mempengaruhi output tahun anggaran } \\
\text { berikutnya }\end{array}$ & $\begin{array}{l}\text { Berpotensi mengurangi output tahun } \\
\text { berikutnya }\end{array}$ \\
\hline $\begin{array}{l}\text { Resiko bertentangan dengan Perpres } \\
54 / 2010\end{array}$ & Masih termasuk kriteria Tahun Tunggal & Bermasalah Pada Definisi Tahun Jamak \\
\hline Resiko bertentangan dengan UU 1/2004* & $\begin{array}{l}\text { Tidak membebani Tahun anggaran berikutnya } \\
\text { baik disisi otorisasi maupun perencanaan }\end{array}$ & $\begin{array}{l}\text { Membebani Tahun anggaran berikutnya } \\
\text { baik disisi otorisasi maupun perencanaan }\end{array}$ \\
\hline
\end{tabular}




\begin{tabular}{lll}
\hline Uraian & Dibebankan Tahun Anggaran Bersangkutan & \multicolumn{1}{c}{$\begin{array}{c}\text { Dibebankan Tahun Anggaran } \\
\text { Berikutnya }\end{array}$} \\
\hline Pemeriksaan Keuangan & sesuai ketentuan. & \\
\hline Pemeriksaan Kinerja & $\begin{array}{l}\text { Berpengaruh negatif terhadap penilaian } \\
\text { akuntabilitas }\end{array}$ & $\begin{array}{l}\text { Tidak Berpengaruh terhadap penilaian } \\
\text { akuntabilitas }\end{array}$ \\
\hline
\end{tabular}

Melihat uraian diatas serta tabel perbandingan diatas, maka dapat disimpulkan bahwa solusi yang paling efisien dan efektif adalah pembebanan dana pada tahun anggaran bersangkutan. Hal ini hanya bisa dengan memanfaatkan fasilitas Garansi Bank sebagai Jaminan Pembayaran yang diperpanjang masa berlakunya hingga maksimal 50 hari keterlambatan. Jaminan pembayaran menjamin bahwa dana anggaran yang digunakan masih berada pada tahun anggaran bersangkutan. Hanya saja dana anggaran tersebut berubah wujud menjadi garansi bank yang dijamin oleh UU No. 7/1992 dan UU KUH Perdata. Disisi lain pelaksanaan sisa pekerjaan melewati tahun tidak melanggar ketentuan kontrak tahun tunggal, karena tidak ada larangan pelaksanaan (kinerja) melebihi tahun anggaran. Batasannya hanya maksimal 50 hari setelah berakhirnya masa pelaksanaan. Sekarang pilihan sangatlah jelas apakah hanya ingin mencapai prestasi Pemeriksaan keuangan dari sisi administratif yang indikatornya akuntabilitas. Atau berpihak pada pencapaian kinerja yang indikatornya efisien dan efektif sesuai amanat UUD 1945 seperti tertuang dalam UU 15/2004. Kalau pilihannya kinerja maka langkah akhir tahun menggunakan perpanjangan Jaminan Pembayaran adalah upaya optimal semua pihak untuk mencapai kinerja. Agar langkah ini dapat memenuhi asas akuntabilitas maka terbitnya aturan/kebijakan perpanjangan jaminan pembayaran selama masa keterlambatan adalah keharusan.

Salah satu terobosan Pemerintah lainnya adalah alternatif pembiayaan proyek infrastruktur melalui Skema Availability Payment. Dalam skema ini, Badan Usaha akan menanggung biaya pendanaan proyek infrastruktur, kemudian investasi tersebut kemudian akan dikembalikan secara berkala oleh Kementerian, Lembaga Negara atau Pemerintah Daerah yang bertindak sebagai Penanggung Jawab Proyek Kerjasama (PJPK).

Berdasarkan Perpres 38/2015, terdapat 19 (Sembilan belas) sektor infrastruktur ekonomi dan infrastruktur sosial yang dapat dikerjasamakan dan dapat diberikan penjaminan. Lebih jauh, PT PII dapat memberikan Penjaminan Pemerintah untuk sektor publik yang secara financial kurang menguntungkan namun sangat dibutuhkan oleh masyarakat misalnya sektor pendidikan, lembaga pemasyarakatan, persampahan dan pariwisata.

Sinthya menambahkan bahwa ke depannya PT PII berpotensi memperoleh perluasan mandat perseroan, antara lain meliputi, penjaminan BUMN dengan skema direct lending dan penjaminan atas penugasan Hutama Karya.

PT PII melalui IIGF Institute telah melakukan berbagai program sosialisasi dan capacity building kepada para pemangku kepentingan yang terlibat dan akademisi melalui Indonesia Infrastructure Roundtable (IIR) yang dilakukan secara berkala atau seminar lainnya khususnya mengenai Proyek Infrastruktur dengan Skema KPBU. Hingga saat ini PT PII telah melaksanakan 13 kali IIR dan Penandatangan Kerjasama dengan 25 universitas di seluruh Indonesia.

\section{Kesimpulan}

Kelemahan dan penyimpangan dalam pelaksanaan pengadaan pekerjaan konstruksi pemerintah secara langsung maupun tidak langsung akan memberikan pengaruh terhadap pencapaian quality assurance proyek konstruksi yang pada akhirnya akan mempengaruhi kualitas infrastruktur. Untuk itu perlu dipastikan bahwa proses yang berjalan dengan baik dimana pemilik/pemerintah harus terlibat secara mendalam pada setiap tahapan dari proses pengadaan. Pelaksanaan pengadaan konstruksi yang sesuai dengan kerangka tata nilai pengadaan harusnya akan menghasilkan proyek yang tepat waktu, biaya dan kualitas yang diinginkan serta mampu melakukan fungsi khusus yang diharapkan. Merupakan hal penting untuk memastikan bahwa pengadaan pekerjaan konstruksi yang dilaksanakan terencana dengan baik serta berjalan sesuai dengan tujuan dan target yang telah ditetapkan. Karena jika kegiatan pengadaan tersebut direncanakan dengan baik, maka akan mudah dilakukan identifikasi permasalahan pada setiap tahapan pengadaan dan rekomendasi perbaikan sehingga nilai manfaat bagi masyarakat dari nilai pengadaan yang dilaksanakan akan dapat dipenuhi.

\section{References}

Use the "Insert Citation" button to add citations to this document.

[1] J. Van der Geer, J.A.J. Hanraads, R.A. Lupton, The art of writing a scientific article, J. Sci. Commun. 163 (2000) 51-59.

[2] W. Strunk Jr., E.B. White, The Elements of Style, third ed., Macmillan, New York, 1979.

[3] G.R. Mettam, L.B. Adams, How to prepare an electronic version of your article, in: B.S. Jones, R.Z. Smith (Eds.), Introduction to the Electronic Age, E-Publishing Inc., New York, 1999, pp. 281-304.

http://www.iigf.co.id 